\title{
Smart Contracting: A Multidisciplinary and Proactive Approach for the EU Digital Single Market
}

\author{
María Claudia Solarte-Vásquez \\ Katrin Nyman-Metcalf \\ Tallinn Law School, \\ Tallinn University of Technology \\ Akadeemia tee 3, \\ Tallinn 12618, Estonia \\ E-mail: maria-claudia.solarte-vasquez@ttu.ee \\ E-mail: katrin.nyman-metcalf@ttu.ee
}

Abstract: Smart contracting (SC) is a proactive proposal to operationalize the relational contract theory for the upgrade and improvement of legally relevant exchange. The dynamic institutional environment of the European Union (EU) is a suitable framework for this proposal. $S C$ addresses the interests of the business management, law and information technology practices with a perspective of influence in digital exchange, communication processes and other human and human-machine interactions. This position paper restates the advantages of the concept by highlighting the practical transition pathway SC offers to moderate the growing haste towards the embeddedness of exchange in automated and distributed models. This theoretical contribution supports the systematization of the proactive and legal design research field, and explains the characterization, operationalization and specification of the SC concept.

Keywords: digital exchange, EU digital single market, relational contracts, proactive contractual management, smart contracting, transactional governance 


\section{Introduction}

This paper revisits the smart contracting (SC) concept and expands it by explaining the foundational components of the approach, describing how and in what context it can be used, and clarifying the disctinctions between SC and 'smart contracts'. SC proposes a reflexive and strategic approach to contracting and contractual management processes, characterized by collaborative and proactive lawyering activities intended to improve the quality of transactions. In this way, it is possible to formulate a relational concept of legally relevant exchange, beneficial to all the stakeholders and more consistent with information and communication technology (ICT) progress. Such an approach would be valuable for managers invested in digital transformation and sustainability, and for the general public who must be offered more accessible legal information. "Smart" in relation to contracts is often associated with automated techniques, but when Solarte-Vasquez et al. (2016) first used the term, it was instead intended to label intelligent, ingenious, qualified, and resourceful contracting processes. These suggest new ways to use collaboration and a user-centred design, Usability (UX) and User Experience (UXI) in any other area of professional contracting, but can equally be applied to computational methods in law.

Differences in the interpretation of contracts and flaws in contract drafting have historically been known to be the leading causes of legal disputes. Dispute resolution and contracts have been identified as the most important legal risks faced by organizations and, in spite of the evidence, professional contracting processes and drafting techniques remain substantially unchanged. Studies also report that most corporate disputes are related to contracts, revealing the correlations between litigation spending and revenue. Furthermore, clients and businesses increasingly challenge the quality, delivery and costs of legal services, and begin to reconsider the need to hire legal counsel in areas where automated solutions could be implemented, for example streamlining and automating legal tasks and routines (Norton Rose Fulbright, 2016). Even when considering the most technically driven scenarios, the legal profession and the legal environment of business may not easily allow deep transformations (Posner, 2005). SC addresses these crucial issues in contractual management, via legal innovation, and from within organizations to contribute to the regulatory quality of exchange in the digital markets.

Terms that qualify SC are that it is relational, collaborative and proactive. It is applicable to transaction design and all interfaced exchange with legal relevance. This paper describes the proposal in detail, including how it can improve the 
current legal environment for mediatized exchange and why the Digital Single Market (DSM) and the EU governance environment supply the most welcoming context in which to apply and disseminate the concept.

This text is divided into three parts. The first provides background information. The second discusses the foundations of SC and its contributions to the systematization of the research field in three self-contained sections with descriptive, discursive and conclusive reflections each. One section on the characterization of the SC explains the relational dimensions and the governance capacity of the concept; the next covers the viability conditions and the EU institutional suitability for the operationalization of the proposal, and the SC guiding principles, and transaction design factors recommended by the approach. The third section compares SC and smart contracts, to specify the status of the two. The last part presents few concluding remarks.

\section{Preliminary observations}

Perceptions on strategic contracting reflected in the literature are predominantly relational (Macaulay, 1963; Macneil, 1980), in part resulting from the powerful effect of the market expansion and exchange landscape, and the imperatives of technological progress. The social and technical systems, however, do not align smoothly. For example, despite the welcoming reception management scholars have given to relational ideas (McLaughlin et al., 2014), the implementation of this perspective still faces strong institutional challenges. This is the background to the proposal made in this paper about the value of SC during transitions, and the applicability of the approach to any legally relevant exchange, especially suitable in mediatized trade interactions and organizational digital strategies.

Solarte-Vasquez et al. (2016) explained how SC combines concepts from theories in law, management and ICTs, departing from an advanced conflict management and dispute resolution perspective, situating this proposal under a relational-proactive denomination. In conformity with that view, SC considers understanding to be the first and foremost goal of legally relevant human exchange. A systematic, principled approach throughout the contractual process and transaction design are the key guiding elements to this proposal, which is meant to be discrete enough not to pose contradictions to the legal and theoretical notion of a contract. Moreover, SC links conflict management and dispute resolution constructs to contract theory at the ontological and epistemological levels, in the interest of efficient, effective and satisfactory transactional-not 
only contractual-experiences. Consequently, SC expands the scope of the alternative dispute resolution (ADR) field, as this area of study is commonly, if not accurately termed, to any manifestation of private and self-regulatory governance in exchange, including contracts, and other free expressions of consent with legal implications. Good contracting is an ADR matter because these activities share purpose.

The relevance of revising contracts and contractual management (Keskitalo, 2006), the general theory of contracts (Dalhuisen, 2013) and contracting under the ADR lens is further heightened by two factors. The first and most recognizable is the migration of most human activities to the global and interconnected digital networks, prompting organizational responses to new interactions and complex exchange. With the opportunities the digital transformation creates arise also tensions and difficulties that more encompassing theoretical constructs would address better than the existing domestic legal systems, and/or local standards. Second, turning to the most pressing factor at present, is the intellectual novelty posed by the growing control of human activities by artificial intelligence (AI) agents. The AI field progresses diffusing the boundaries between the physical and the virtual worlds, while blind to philosophical, sociological and organizational debates currently gaining momentum (Ebersold \& Glass, 2016; De Cremer et al., 2016). Furthermore, the AI community has been reluctant to engage with the super-intelligence discussion in terms other than machine learning progress and the Internet of Everything (De Matos et al., 2017), leaving concerns on how to ensure this evolution takes place in people's best interest to other disciplines.

In business and governance, several schools of thought may accommodate relational views of legal exchange. Among these are the stakeholder's theory and the dynamic capabilities theory. Stakeholders' theories such as Freeman's (1994) see companies as a bundle of strategic interconnections between entities and individuals, opening ways to review value creation on the basis of interactions, taking into account the complexities of human psychology (Bridoux \& Stoelhorst, 2014). The dynamic capabilities theory (Teece, 2007) allows stating that improved contractual management competences complement other capabilities of the firm (Bagley, 2005). Additionally, within the subset of organizational economics, institutional economics and business research have been fruitful to the point of providing new economic efficiency narratives such as the contract theory by Hart and Holmström (Izmalkov \& Sonin, 2017). These developments have narrowed the gap separating economic thought from the dynamism of social and economic activities, and from the legal implications of the current entrepreneurial market system (Foss \& Klein, 2016). 
To end this referential background, a few more terminological details must be added in respect to contract and contractual management functions, or the administration and governance of contracting processes, respectively. Contract management professionalized an independent practice that popularized the treatment of contracts as assets, and of contracting as processes with decisive influence on industrial and project management models (Kähler, 2013). From this perspective, every phase of the lifecycle of a contract, from negotiating and drafting to execution, can be monitored and optimized for efficient risk management and costs reduction (Romzek \& Johnston, 2002). Contract managers lead the dialog on the future of contracting from an assortment of academic, professional, and official platforms. For instance, the International Association for Contract \& Commercial Management (IACCM, n.d.) has recently embarked on the promotion of digital transformations via automation and the use of computational methods for public and private contracting. Contract management, however, is not strong at the relational and strategic ADR levels, leaving aside much of the wider governance concerns now crucial for enterprises. Keskitalo (2006) formulated the contractual enterprise risk management theory adding other organizational goals, and expanding the capacities of contract management.

Similarly, the SC's conceptualization is not only about administration, but also about governance. SC can be applied to both contract and contractual management, adding principled components and a more concrete relational character to these complex processes without discarding highly routinized and so-called 'spot market transactions' (Argyres \& Mayer, 2007). Contrary to what the authors stated on these, the SC approach claims that better understanding of transactions may have a significant effect on human dispositions and consent. Improved 'spot market transactions'-mainly low intensity consumer contracts - and non-specific transactions (Williamson, 1979) should be a most helpful intervention in guiding interaction and preventing consumer disputes between parties, especially in the digital markets. 


\section{Foundational components of smart contracting}

\subsection{Characterization}

This section explains separately the relational and governance dimensions characterizing SC, although functionally the two are intertwined. SC pays tribute to Macneil's relational contract theory and emphasizes its far-reaching implications on private governance studies or the strategic regulatory role of wilful and collaborative exchange (Macneil, 1980).

Macneil (1999) presented four propositions according to which it is possible to determine whether a theory qualifies as relational. These propositions explain the suitability of the SC approach and justify the SC's overreaching goal of scaling up improvements in micro-level transactions in the interest of human interactions of the digital and mediatized exchange in particular. SC is also a private governance concept, enriched on two counts; one is the strategic potential of the approach, accruing dynamic capabilities for organizations, and subscribing to a multistakeholder principle; the other is the emphasis on non-traditional regulatory techniques (law by design) for the upgrade of organizational performance. This last feature reinforces the relational paradigm and opens up opportunities for innovation and cross-disciplinary exploration about information architecture in contracts, and contracting as knowledge management system. Macneil's general theory is said to have swept the contracting field in legal scholarship and added new dimensions to business studies, with strong impact on the evolution of organizational thought (McLaughlin et al., 2014).

Macneil's approach was influenced by Macaulay's exploratory research (1963), which provided empirical grounds on the inadequacy of the dominant assumptions about the realities of contractual governance. Both scholars challenged the chief contractual paradigms on transactions and exchange of the common law tradition, in a way closing the gap with the doctrinal legacy of civil law systems. The relational theory persuaded that "Contracting rests on moral foundations" (Campbell, 2004, p. 645), and thus, must become a principled process (Gunningham \& Sinclair, 1999). The formulation of frameworks with relational components like SC may overcome the perceived ambiguity of the original relational theory denounced by critics (Barnett, 1992), and should help make a more realistic sense of the growingly complex and continuously changing models of exchange of the digital economy, at levels hardly discussed before. These levels are at the core of Macneil's contribution, referenced with undeserved simplicity for the sake of brevity, as composing a social matrix for meaningful exchange with ontological and 
ideological aspects, and adding solidarity or social cooperation (Macneil, 1980).

The background of structured societal support for contractual relations, which in this case focuses on the EU institutional normativity, are the 'external rules' providing a framework, whereas 'internal rules' reflect norms or principles of action. The principles contain ten operational attitudes for 'proper exchange' and 'contractual solidarity' (Macneil, 1983). Internal rules represent the cooperative effect of relational contracts, and in close observation, they make it difficult to admit other kinds of exchange. These rules cannot be set out fully here, but may hold interest for sociologists interested in re-appraising the realities of exchange, one contract at the time.

\subsubsection{Relational dimensions of SC}

Macneil's contribution became an umbrella theory inviting adaptations, specification and elaboration. SC responds Macneil's call to complement the conception of the essential relational contract theory (as renamed in 1999) with context-specific developments, by considering transactional behaviour aspects within specific complex exchange environments, principally the governance models and opportunities enabled by the EU regulatory system.

The relational theory can be compared with subsequent ones according to concepts and criteria Macneil refined over time. He talked about contracts in general, and identified some elements common to collaborative exchange like cooperation, economic exchange, planning for future, potential external sanctions, and social control. (Macneil, 1969 cited in Campbell, 2004a, p. 7). From the original list (Macneil, 1980), four are easily identifiable in the SC approach, and compatible with EU policies on regulations: mutuality or a winwin logic providing positive incentives for compliance; contractual solidarity or the intent to preserve relationships affected by the exchange, as a sustainability factor; creation and restraint of power as contracts are strong governance tools in the digital governance; and, very importantly, harmonization with the social matrix, because the SC operationalization techniques are specifically geared to represent relationships according to the expectations of the institutional environment of the interconnected collaborative and multi-layered economy.

The criteria that characterize relational theories derive from four core propositions on recognition, awareness and understanding of the complexity of transactions, the relationships they regulate, and the context or web of relationships they are nested into (Macneil, 1999). The same assumptions can be identified in the SC proposal, which contextualizes and operationalizes the theory for practical applicability. 
SC considers the complexities of digital markets and peculiarities affecting interactions of interconnected agents in trade, hence, the heuristic approach to transaction design regarding minimum standards for adaptability and flexibility: (a) any transaction is just one of many forms of exchange and represents only a fraction of the underlying relationship(s), and (b) even single and low intensity relationships are complex due to the environment where they take place and the enormous availability of competing choices of the digital markets.

The "enveloping relations" (Macneil, 2000, p. 881) between contracting agents are better understood, as well as the factors affecting these relations: (a) sustainable and proactive contractual management aims at quality based on standards of efficiency, effectiveness and satisfaction, which are accomplished only if a well-informed strategic planning takes place; (b) transaction design that follows a consumer-centered approach necessarily studies all relational layers as well as the institutional context of each; (c) exchange dynamics, rather than singled transactions are the main interest of contracting processes.

The built-in collaborative features of SC demonstrate solidarity and more compatibilities than differences between the relational character of the view and the classical-liberal theory of the contract, bridging tensions between the two (Mack, 1981). SC holds highest the value of freedom in contracting while at the same time commits to the empowerment of the contracting agents beyond the legal standards, by non-legal means. To accommodate the relational character of exchange, the classical theory does not need to be dismissed. Plausibly, reconciling the two could happen if applying the classical law of contract to the formation of agreements, and the relational theory to the pre-contractual and post-contractual phases as well as to other types of interactions with legal relevance.

Whereas Macneil may not have held consent so highly or admitted wilful agreement to have a too far-reaching and definitive extent, SC touches upon those issues, contending authenticity when resting on largely indecipherable and specialized text. Consequently, SC questions the validity of agreements when legal obligations are imposed on the basis of meagre expressions of accord, sometimes in disregard of other indications of intent (or lack of it). A typical example is the 'click-wrap' license agreement, which has been of interest to EU law-makers from a consumer protection viewpoint because of the distorted process in the formation of such contracts (Böhme \& Köpsell, 2010).

SC went from transactions onto other forms of exchange, permitting a more complete analysis of human interactions, looking at a wide spectrum of 
personal, social and community behaviours, expectations, trends and informal institutions. In terms of legislation and public policies, SC fits the EU participatory, reflective, and dynamic governance landscape, and may rely on the resilience of this institutional backup to safeguard innovative and alternative exchange models. SC seeks to transform traditional strategic contracting and expand the risk management aspects (securing enforceable bonds), upgrading the contracting experience of the parties by adapting to the requirements of the times and exploiting the opportunities technology offers. The characterization of SC as a relational private governance concept in strategic contracting and contractual management, marks its separation from rational choice theories and others with interest on competition, individuality and exclusion.

\subsubsection{The governance capacities of SC}

Governance can be explained as an organized system encompassing direction, control and management aimed at the collective wellbeing, exercised at various levels by legitimate sources of authority, and founded on formal and informal institutions. This broad perspective includes autonomous governing and self-regulatory capacities that support change and processes of regulatory adaptation, learning and experimenting (Stoker, 1998; Goodin, 1998). Rules and order are manifestations of governance activities, and the main subjects of governance studies, like the private regulation of trade relations as exercised through contracting, transacting and exchange. SC is a governance concept and a way of performing governance capacities that recommends improving organizational behaviour with the implementation of a responsive and dynamic evolutionary approach. What holds true as a good regulatory solution now to arrange interactions within a given organizational context, does not necessarily help accomplish the purposes of exchange in the future.

Contracting is a lawyering task commonly entrusted to contract management professionals interested in compliance, engineers, investors, and often in late stages, legal experts. 'Transactions' are understood as 'legal acts,' mostly in exercise of the rights and duties of the parties, and where the underlying deeds and deals are somewhat dimmed, whereas 'contracts' refer to wider, more complex processes that express, for example, how entitlements emerge on the basis of intentionality and consent (Barnett, 1986). Contracts create entities, shape organizations, establish all legally relevant connections, and formalize the commercial activities that support trade. The term governance could be further attached to contracting as in the means of managing, steering and producing a normative order (Stinchcombe, 1985). 
For the purposes of smarter contracting processes, transaction design standards and formats must be flexible, responsive to the socio-technical environment, and in support of agreements for mutual and long-term gain. In this light, SC holds genuine interest about the effects and affordances of novel technologies in contracts that could promote real transformations in the traditional governance of businesses and the markets. It considers that to support efficient, effective and satisfactory exchange, digitization of legal services is needed, but not enough. Simple SC adjustments such as the observance of principled guidelines during planning and novel techniques for transaction design can upgrade and transform traditional and digitized interactions. A relational contractual governance view and practices may diminish the negative impact of conflict, and legal disputes, which in fact concedes to notions on transaction cost economics. Negotiating, contracting, transacting and executing agreements, categorized in the ADR way, rely on more purposeful processes aimed at mutually beneficial outcomes to incentivize compliance and reduce disputes (Lumineau \& Malhotra, 2011).

Excessive reliance on legal standards, litigation and other state-dependent procedures is discouraging because of the limited capacity of these mechanisms to provide satisfactory redress, their rupturing effect of adjudication upon vital institutions, and the disproportionate amount of resources that legal procedures consume (Marshall et al., 2004). However, the conventional wisdom in mainstream economics indicates that only some contracts could be designed to preserve underlying relationships and promote harmony and continuity. Others, the so-called non-specific transactions (Williamson, 1979), are supposed to be less affected by sub-optimal drafting; commercial contract management strategies still assume that simpler contract types mean less complex governance relationships and vice versa (Ivens, 2002). Proactive contracting instead expects major gains from better low-intensity consumer relations, where relational aspects are commonly neglected, and from interactions within organizations. Benefits could be made to outweigh additional transaction costs caused by longer contractual cycles or expenditures on specialized transaction design. No transaction is without a cost, but none is merely a cost. These could be seen to facilitate, directly or indirectly, certain relationships. For SC all exchange is relational, and when mediatized and digital, a prime candidate for enhancements and upgrades, in attention to values such as social responsibility, sustainability, participation and freedom.

The governance capacity of SC embraces a principled approach to contracting upgrades with strategic value conveying a notion of collaboration (SolarteVasquez \& Rungi, 2017) that is not entirely new. DiMatteo (2010), for example, explained the uses of contracts in the creation of value and the maintenance 
of a sustainable competitive advantage, and stated that contracts provide the core mechanisms for interaction in transactional law, including dispute resolution. Also, Poppo \& Zenger (2002, p. 712) identified improvement in exchange performance resulting directly from relational governance and contract customization. SC compares with few other proactive initiatives in the contractual management field and the legal design stream of practice. But in general, except for some instances of functional private governance microsystems such as Ebay or Paypal, governance institutions/schemes are poorly equipped to enable alternative strategies or to deal with complex (Gunningham \& Sinclair, 1999), wicked (Termeer et al., 2015) and emerging problems such as the challenges of legal automation and the use of computational methods in the interpretation of rules.

SC allows contract-based strategic collaboration and innovation, and promotes relational sustainability. Smarter contracts are adaptive and less rigid in order to resist the impact of disruptive change (Cruz \& Marques, 2013). Responsiveness in transaction design processes adds to the flexible handling of exchange, and for doing that, the SC approach is reflexive across the entire contractual cycle. A proactive contractual cycle would include the stages shown in Figure 1: planning (in consideration to principles and corporate governance goals, to permit alignment); negotiation and preparation of texts (transaction design, prototyping and iteration); the text/interface of the agreement (mediatized in digital transactions); and compliance or post-contractual adjustments (renegotiation), monitoring, and conflict management and dispute resolution stages when needed. While the traditional governance based on transaction costs economics and the basic contract management focus on the fourth stage (Williamson, 1981), the SC proposal would have greater governance capacities and become the most valuable during the second and third stages.

Changes in technology and the digital transformation put the quality of the regulatory governance of organizations to the test and created sustainability issues. In this respect, the capacities to produce and adopt smarter regulatory products (responsive, as a result of reflective processes, and resilient due to their adaptive and dynamic nature) become decisive. Sustainable governance is an expression of the vitality of systems in developmental studies (Voss et al., 2006), but also appropriate to corporate governance strategies, from the perspective of the relational view of exchange. Sustainability is about stability and processes that can be maintained without causing harm to a system or its parts, so in strategic governance by means of private contracting, it requires the identification and reduction of stakeholders' tensions and the pursuit of the general well-being. Such business strategies involve additional corporate social 
Figure 1. Contracting cycle in contract and contractual management

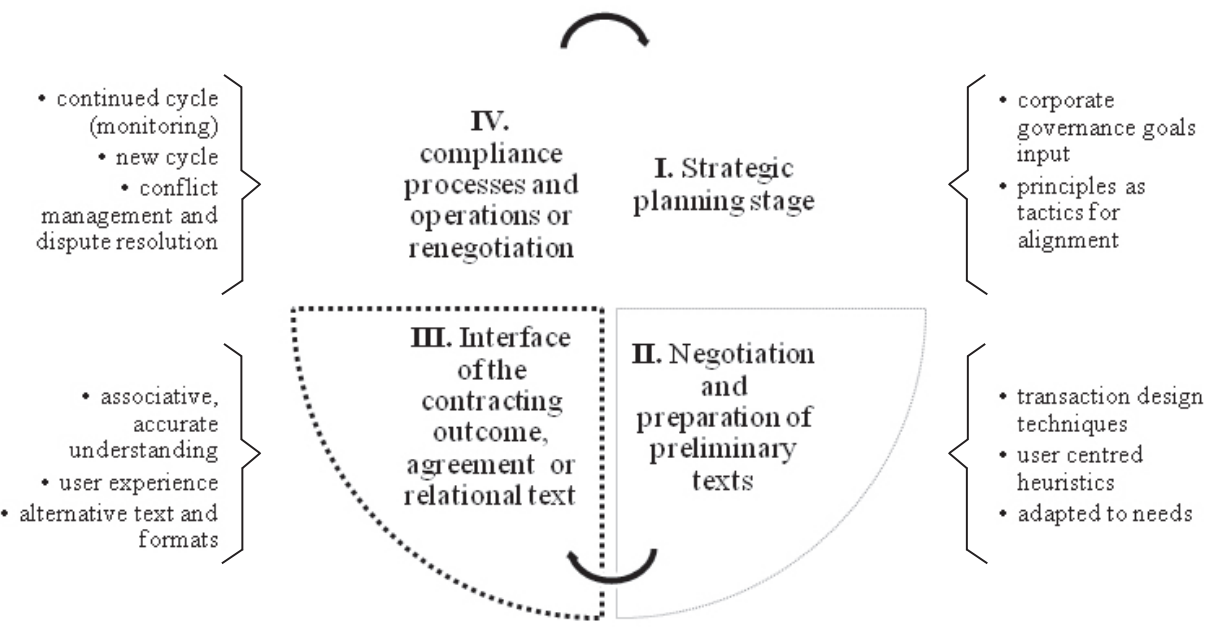

Source: Original synthesis of a contracting cycle drawing in part from Jaakkola's brief (2004)

responsibility components, which support long-term viability of the socioecological trade system as well (Van Marrewijk, 2003). Corporate sustainability could also be seen to depend on collaborative, relational and proactive processes where better contracts could induce compliance in accordance with strategic corporate goals. The $\mathrm{SC}$ is a concept that contributes to reflexive governance concerning the values invoked by reflexivity: integrative judgement, careful justification of policies and goals, and legitimacy (Voß \& Bornemann, 2011).

Legal innovation, interdisciplinary collaboration and professional contractual management are options for organizations to optimize the handling of operations while coping with external factors from the greater institutional and regulatory frameworks. Discarding the importance of these as proactive dynamic capabilities (Rindova \& Kotha, 2001; Zahra \& George, 2002) would be unresponsive to the requirements of the times, perplexing for some of the stakeholders, and can place companies at a disadvantage, at least in the digital markets.

Overall, under the dynamic capabilities approach, the corporate areas where SC governance capacities could become beneficial if embedded in contractual management processes are: risk management; transaction design for proper communication, association and engagement rather than control; and, intrafirm information management and coordination across strategic levels via selfregulatory documents. This integrated view of the whole regulatory system of an 
organization reflects an instrumental and contractarian understanding of contracts (Van Oosterhout et al., 2006). In addition, to realize the potential of a smarter regulatory governance, the early participation of proactive lawyers is key, as it is to consolidate the legal strategic competences at every organizational level for internal relational alignment. Figure 2 illustrates where in the business strategy levels collaborative governance can be an advantage, and how it is initiated from above but nurtured by feedback from the operational processes at the bottom. Collaborative interactions between the organization and external stakeholders would affect consumer contracts at operational levels, alliances and partnerships at managerial levels, and investments and projects at the community at large from the corporate level. The governance capacities of SC can be said to be cross-disciplinary versions of the dynamic capabilities of enterprises (Nylén \& Holmström, 2015).

Figure 2. Strategy levels and areas of collaboration

I Business Corporate Level Strategy

(Vision: goals, sustainability, social responsibility, responsiveness)

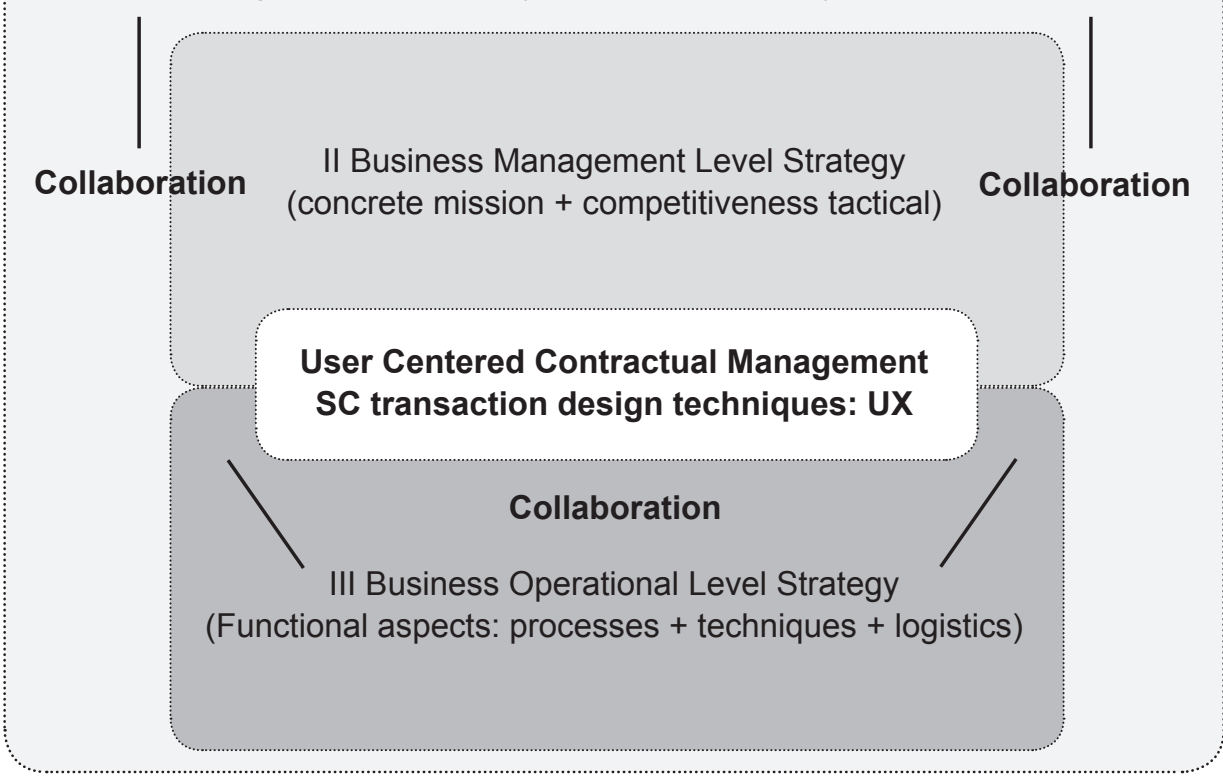

The transactional quality achieved by smarter exchange interactions may condition economic development, if synergies are achieved between normative systems, emerging contracting patterns, and technology. SC clearly is an integrative governance concept which can be applied to narrow interactions 
and all components of purposeful exchange, in every organizational level, and culturally neutral, which makes it transferable. Contracts and transactions could be aligned with the values in policy and social discourse without interfering with the legal conditions of validity or the theories of contracts. Good contractual management is a capability that the emerging transactional governance by code such as the so-called 'smart contracts' cannot match, notwithstanding the enormous potential of these applications (Fairfield, 2014).

Private contracting may be the oldest self-governing activity to represent exchange and transactions and to engage agents in relationships where rights and obligations are created, modified or extinguished. Core to the function of contracts is to legally formalize these interdependencies according to a protective background established by the state, based on legal acts performed by capable individuals, voluntarily, and regarding licit and attainable goals (Mack, 1981). SC respects these rules and other limits set by law to the individual autonomy, but considers that empowerment rather than entitlement should guide the negotiation, formation, and interpretation of business contracts, especially if to impulse the digital economy and reduce the intervention of states in high volume and low impact exchange. At the same time, SC upholds the role of consent (freedom, self-governing, choice, and responsibilities) and mutuality (fairness, equity, and justice), as essential theoretical grounds to preserve from the legal doctrine (Mack, 1981).

Empowerment via functional governance competences is primordial now when the ICTs and their derived platforms and applications increasingly develop an independent normative influence on businesses and people's affairs (Kar, 2016). The legislator is likely to react the only way it can: producing laws, imposing protective requirements, substantial or procedural, and establishing limits (the duty to document negotiations, legal locks, etc.). This justifies the need for novel private regulatory initiatives to reduce, in a timely manner, the impact of change and to help to adapt to new formats and procedures independently. The convenience of a 'soft' intervention such as the redesign of interfaces sufficiently tackles neglected aspects of exchange, updates and improves the quality of transactions and may have the much-needed positive effects on digital trade for it to thrive.

Computational methods in contracting, mistaken by empowerment, may shake the foundations of the law, by reconfiguring the notion of freedom, and disabling all advancement in terms of consumer protection and contractual fairness achieved in the past century in Europe (Wilhelmsson, 2004). Automation will not be contained for long, in spite of this and the relational contracting strongholds 
within management. This urges for legal UX and UXI work and smarter exchange processes to improve understanding and informed control over transactions. Automation should not happen in the absence of fully informed and explicit consent, for which human participation must be enabled, verified and safeguarded from unfair and abusive practices. The deployment and diffusion of SC practices would provide assurances for a continued human involvement in contracting.

\subsection{Operationalization}

\subsubsection{Social and EU institutional backup for the SC relational proposal}

Responsive governance schemes at the contractual level respond to the trade and exchange needs identified by reflexive process, but are also proactive and resort to purposeful innovation when conditions are favourable. Good understanding of the institutional environment (social, technological, legal, and cultural) provides context and a grasp of conditions for the successful deployment and diffusion of innovative proposals (Malerba, 2002, p. 257). This strong institutional knowledge characterizes relational contract theories and permits a well-informed exercise of consumer/user centred practices in contracting. Also, an ampler view of the complexities of the institutional environment informs regulators about the opportunities and constraints available to formulate more effective and diverse forms of social influence and control. This subsection introduces a short contextualization of the SC proposal with an overview about the basic social preconditions of viability and the formal legal and policy instruments identified in the EU that legitimize the approach.

SC relies on two assumptions about people's interests and competences, sufficient understanding and appreciation for collaborative exchange, and responsible selfagency (Solarte-Vasquez et al., 2016). Collaboration is described by SolarteVasquez and Rungi (2017) in contraposition to exclusion and competition to indicate relational, sustainable and inclusive values, while self-regulation, according to Ryan and Deci (2006) is a motivated, autonomous determination and decision-making competence, linked to wellness, productivity, and quality performance. Self-regulation in industry and business draw rules closer to agents enhancing information and understanding levels; in addition, it has been found that self-regulation may help adopters become more competitive, raising industries' standards (Commonwealth of Australia, 2000). Both conditions reflect advanced personal agency competences that validate contract-based innovation for the strategic advantage of organizations. Regarding trade-offs, increased responsibility during contracting could be the most noticeable to result from the institutionalization of SC practices for customers. Organizations, in 
turn, should give up control in favour of more open, participative and inclusive contracting processes, and possibly change resource allocations to cover for the re-design of legal documents. If collaboration and self-regulation are not part of the social and organizational culture, behavioural change measures are possible, but at higher and more intrusive costs (Bilz \& Nadler, 2013). It may be so that contractual innovation in environments highly dependent on legal standards may succeed only with the acquiescence of the legislator, by coercive and/or normative pressure (DiMaggio \& Powell, 1983).

Although SC focuses on private regulatory initiatives, international and supranational organizations, states and other public entities remain key stakeholders. These establish the formal institutional background to which exchange activities must conform, or from where traders can derive a greater comparative advantage (Ahmadjian, 2016). The EU is an exemplary evolving structure especially fertile for regulatory innovation where values can be generally implemented, scaled and realized within the system at relative ease (Van Ham, 2013; for contrast see also Kerikmäe \& Särav, 2015). The theoretical contributions of SC get comfortably legitimized within this institutional context regarding, in particular, the opportunities arising from the businessconsumer and other interactions taking place in the DSM of Europe (European Commission, 2015b). The most relevant formal institutions to SC are the policies and regulations on better rules, the digital agenda, ADR and about selfregulatory mechanisms, and consumer protection.

While the EU has paid attention to issues of empowerment, self-regulation, access to justice, private redress, accessibility of use of ICTs, and the simplification of procedures, it had not addressed the impact of consumer experiences in trade until recently. The digital agenda has focused on consumers, and with it the phenomena of exchange acquires a new significance (EESC, 2017). The interest on regulatory quality and effective governance is seen from the early 2000s in the various initiatives to improve legislation inside the Union to strengthen the single market, following the comprehensive assessment contained in the Mandelkern Report (European Commission, 2001). In 2003, the European Parliament, the Council and the European Commission (EC) concluded an Inter-institutional Agreement on better law-making to improve the quality of regulations and in support of alternative methods as a way to implement the principles of subsidiarity and proportionality. In the Action plan 'Simplifying and improving the regulatory environment' the Commission mentions self-regulation among the appropriate legislative instruments, referring to the practices, common rules, codes of conduct and voluntary agreements which economic actors establish to regulate and organize their activities (Communication COM/2002/0278 final). 
The EC has also stated in the DSM strategy that the challenges brought about by new technologies and hyper-connectivity require cooperative voluntarism or the participation of the community to sharpen the regulatory performance, create new relationships more apt to produce smarter regulations and to deliver societal goals (Communication COM/2012/746 final). It has become clear for regulators that norms must be fit for purpose and adaptive so they remain applicable when social, technical and political priorities change.

Other special developments of the regulatory capacity of trade agents fall under the category of better regulation and governance, such as initiatives on EU contract law (Cafaggi, 2007; Hesselink, 2015); consumer legislation and policies (Schulte-Nölke, 2015); access to justice and ADR in direct connection with the digital agenda and the DSM (Cortés, 2016); and electronic commerce, to name the few that can relate to the SC proposal. ICTs are now used to achieve these supranational goals, in the field of ADR with the ODR Regulation (European Commission, 2016), for example, but in respect to the smallest components of the governance of the EU, low intensity and consumer transactions, a lot of work must still be done. Nyman-Metcalf and Täks (2013) find that several suggestions in the areas of legislative improvement and simplification qualify to various degrees for automation, and emphasize on that the use of ICTs can help in almost any domain (Nyman-Metcalf \& Täks, 2013, p. 268).

More contracting and contractual management rules and policies are scattered across in normativity of various kinds but lately all connecting to the DSM, where implementing independent contracting models like SC would be swift and empowering (Kar, 2016). New self-regulatory and co-regulatory governance models emphasize the role of private rule-makers who may gradually become institutionalization agents in their sectors. Therefore, industry associations, standardization bodies and companies must be better equipped to manage legal issues, and to develop novel exchange strategies.

The EU has promoted smarter regulation and more intelligent governance methods, inspiring reforms across the continent. For example, in 2009, the European Economic and Social Committee issued an opinion on the contributions of proactivity to better regulation (Opinion 2009/C 175/05). The text includes suggestions about collaboration and self-regulation in terms of communication and participation adjustments, such as drafting rules as readably, comprehensibly and straightforwardly as possible, and in close collaboration with their users. To ensure the connections between regulation and real-life problems, the opinion recommends opportune and effective participation of stakeholders in a continuous dialogue, which closely resembles an exercise of reflexivity 
(Baldwin \& Black, 2008). In the same line, the opinion states that social and ethical aspects should be part of impact assessment processes during legislative procedures, with greater attention to the opportunities for the promotion of freedom of contract, self-regulation and co-regulation when adequate. ${ }^{1}$ As promoted by $\mathrm{SC}$ for contracting, the legislator is supposed to run quality checks to make sure that normative information is well presented, accessible, and eases compliance, tying up with other simplification efforts supported by the EU mentioned above and rules on consumer contracts (Directive on electronic commerce, see Directive 2000/31/EC).

The EU agenda for growth, digital and more consumer-centered, aims at restoring confidence in the economy, helping the empowerment of consumers and their association with other economic agents to facilitate sustainable policy synergies. Novel contracting practices can provide impetus to the DSM, especially if the social and consumer protection focus is maintained (European Commission, 2015a; 2017). SC matches and complements EU legislation and policies, tackling some of the problems that gave rise to the consumer protection regulation in the first place such as the issues of information asymmetry. Creating trust in nontraditional contracting processes is a challenge, but this may be the simplest way to close the gap between the expectations of the public and the capacity of public and private governance schemes to meet them. Transaction design revises formal agreements to structure robust governance models representing the interests of the stakeholders, able to withstand the difficulties of change and uncertainty. Disputes and transaction costs about the interpretation of contractual provisions may be dimisnished as a result (Schwartz \& Scott, 2010)

The complexity of the EU institutional environment system could limit the development of alternative contract formats, and SC, because of the contradictions that arise. One is the EU's excessive reliance on laws, which opposes the declared intent to build more self-regulatory capacities and means of governance. On the possible scenarios for regulatory improvement, the European Commission still highlights risks and the difficulties of enforcement and on the consumer acquis, promotes more consumer legislation. Instead, by SC standards, the most important ways to ensure consumers' rights, especially to optimize digital exchange, are empowerment, information management and mediatized human interaction, and contractual freedom.

The last institutional aspect to mention is the development of the legal profession.

1 See more on the Report on The Current State of Co-Regulation and Self-Regulation in the Single Market (CESE 1182/2004), and the Opinion on The Priorities of the Single Market 2005-2010 (CESE 376/2005 of 7.4.2005, point 3). 
Technology has affected the provision of legal services as it has all other fields giving rise to a growing legal tech movement which has succeeded like no other before in creating awareness about the need to transform lawyering methods. Greater digital skills, digitalization of routine tasks, simplification and legal informatics updates such as 'legalware' development for big data analytics and other applications are in high demand. In contrast, the interest among lawyers to encourage creativity and innovation in non-technical areas, is less noticeable. Legal standards are still used authoritatively, in a strong competitive manner, distributing and excluding; and incentives for antagonistic dealings continue to exist (Hollander-Blumoff, 2016; Menkel-Meadow, 2017). Legal education has not changed significantly either, despite the interest in reforms (MenkelMeadow, 2013); the same can be said about the judiciary and other dispute resolution scenarios. The strengthening of the technical literacy of practitioners could distract from looking at the emerging modes of thinking that really affect private governance patterns, legal theory and some of the most critical aspects of lawyering (Feigenson, 2014; Jackson, 2016; Solarte-Vasquez et al., 2016).

In sum, the EU normative context is an innovation-friendly governance scheme where the SC relational conceptualization can be framed, and related to a concrete legitimizing institutional backup. The EU itself is an example of adaptability; albeit constant transformations, a fully functional versatile and inclusive multilayered structure is preserved throughout, without disturbing the fundamentals of normative integrity (Stephenson, 2013). The EU encourages a wide range of stakeholders to model normative expressions and participation in scalable schemes of governance. This choice of context does not deny limitations, but underlines the diverse institutional enablers permitting the implementation of the smart proactive (reflexive, responsive, human-centered) relational, sustainable approach to contracting at hand.

\subsubsection{SC Principles and UXI factors in transaction design}

\section{Transaction design principles}

The SC approach formulates a coherent and functional contracting strategy that unifies values into guiding principles, and integrates basic standards in legal drafting, UX and UXI essentials drawn from the field of Human Computer Interaction (HCI). The principles relate to the characterization of the approach, in pairs. SC is an operationalization of the relational theory/governance of exchange, founded on the same core propositions or principled, and with special interest in collaborative contracting models. The strategic nature of SC and its proactive developments are the result of risk management considerations, 
and aim at alleviating the costs of poor drafting and antagonistic contracting processes. Finally, the increasing interdisciplinarity and technology-driven support to lawyering processes inspire a truly transformative movement combining legal tech and innovations.

Principled. SC processes are purposeful and take into account the interests and needs of all parties, in accordance to the conflict management and dispute prevention and resolution nature of the concept. Methodologically speaking, SC aims at maximizing mutually beneficial outcomes on the basis of well-calculated and substantiated choices. These are more demanding and complex contracting processes, because they are relational, but also more creative, participative and engaging. The problem-solving style in integrative contracting rules out some of the distributive (non-cooperative) bargaining incentives of traditional contracting and recent automation trends.

Collaborative. In principled and integrative exchange parties are helped via empowerment, and viewed as associates in determining how to allocate rights and assign responsibilities. This reflexive and responsive mode of governance follows corporate mission trends on sustainability and meets policy standards and the expectations of the participants in digital trade environments. The flexibility of the SC techniques is in part about the use of alternative formats, texts (visual, graphic, augmented, lean, etc.), and features, to accommodate contracts and transactions to the needs of the agents. This 'UXI-fied' relational contracting approach is a centrepiece of the SC contribution to organizational economics, that does not dismiss the transaction cost economics considerations dominating the empirical study of contracts (Macher \& Richman, 2008).

Strategic. Smart exchange practices align with corporate level goals in terms of sustainability (long-term survival), prosperity and socially responsible growth, on the basis of stakeholders' satisfaction, regulatory flexibility and technical and social innovation. Managers may bring these higher-level goals from the corporate level onto business operations through contracting, and across the organization in internal documents and communications. Strategically speaking, the logic of smart regulation, public or private, includes the responsible, autonomous (self-regulatory) use of multiple instruments, and with the participation of more actors than the traditional ones which are presumed to be closer, interpret better and react faster to the regulatory needs of society (Gunningham et al., 1998).

Proactive. SC transaction design techniques applied normative relational documents (regulatory texts, contracts, codes of conduct, transactions, etc.) are oriented towards prevention and the creation of incentives for compliance 
and satisfaction. This way of lawyering follows naturally from the greater understanding in collaborative strategies, of the needs and interests of the stakeholders and the regulatory environment. User-friendly transaction design solves understanding deficiencies and should improve trust in legal relationships (Berger-Walliser et al., 2017).

Interdisciplinary. Smart contractual management differs from other approaches by engaging experts and representatives of the main stakeholders from the fields of business, law and ICTs, bridging interests and harmonizing languages, understandings and methodologies. Broader regulatory influences and interactions and the legitimation of different groups require professional and diverse backgrounds, and taking into account standards different from the law and economics, which is the case of contract theories, already under strong strain to meet the requirements of the global digital economy (Braithwaite, 2011).

Technical. This last principle involves being up to date to deliver confidently at the legal, managerial and technological levels considered by contractual management. Professional cooperation unifies technologies and methods that can enhance exchange and improve performance without compromising standards. Mixed expertise, partnerships, and systemic digitalization may address the innovation lag afflicting the legal profession. Shifting from competitive and antagonistic contracting methods towards more amicable, usable, and more likely to minimize the risks of disputes has no drawbacks. Proactivity for SC requires the support of ICTs solutions to reach out in tech-savvy communities, where collaborative features can be embedded in legal products, experienced, and tested using HCI methods. Standardization, professionalization, and digitalization are acceptable means to upgrade contracting but to avoid formalisms that may bring the contracting activity back to stiffness and unresponsiveness, a very careful balance should be found between the adaptive character of SC and the shaping standards, as well as the ones already in place.

SC principles shares with Mandelkern's proposals aspects on accountability, accessibility and simplicity. The dimensions or indicators of quality in regulatory processes impact assessment and consultation, according to the report, reflect relational governance as well as principled and collaborative principles. Quality of simplification, strategy for access, design, and quality assurance fall under the proactive, strategic and technical principles of SC.

\section{UXI factors in transaction design}

The UXI taxonomy of factors for the drafting and design of legally relevant texts also belongs to the functional and tactical aspects of $\mathrm{SC}$, and a very recent 
contribution of the approach to the legal design 'toolbox'. Originally, UX is a quality attribute defined in $\mathrm{HCI}$ by the ease of use of designs, measured by the simplicity and effortless interaction between users and systems. Communication and accessibility improvements may enhance the UX of binding texts without degrading agreements or transactions, except in instances of non-conventional representations fully replacing language: the validity of visual legal categories is not merely a UX concern but a matter of legal theory and semiotics (SolarteVasquez et al., 2016). Nonetheless, both the layer of the graphic interface in mediatized contracts and other regulations for display on a device, and the underlying legal relationships of legal texts, static or dynamic (interactive), will increasingly be defined by their UX and accessibility.

The boundary object concept has been used to tie contractual management to UX and information architecture (Passera \& Haapio, 2013). It also emphasizes the recommending power of proper knowledge communication as legal interfaces display interaction possibilities to users/contracting agents. Interfaces allow shared meanings and simplify the complexity of the system they represent, ultimately facilitating understanding and consent. Contracts are typical boundary objects to be shared by groups but likely to be viewed and used differently.

Although the effects of visualization may result in misrepresentation and liabilities, also the use of persuasion techniques is in question, in here the assumption is that contracts and other legal documents are valid, convey accurate information, and induce compliance to the satisfaction of all parties. Some adjustments for cognitive enhancement constitute a meaningful advancement for the improvement of regulatory quality, and these are all related not to adorning but simplifying and leaning legal texts. The findings of the first EU study on the consumer attitudes about regulatory complexity of the general terms and conditions of contracts, corroborate the need for usability adjustments such as readability, simplicity, accessibility and information architecture and visualization. (Passera \& Haapio, 2013, p. 13) ${ }^{2}$

Table 1 summarizes the combination of drafting standards and UX principles proposed by Solarte-Vasquez et al. (2016) when the SC was initially introduced. This selection of usability factors composes a practical checklist to be used on transactional design during contracting processes.

2 The study also inquired on formats to present consumer information, addressing the information and knowledge architecture issues including the availability of information in pre-contractual stages, and accessibility of graphic text and icons. 
Table 1. Abridged taxonomy of UX factors for transaction design

\begin{tabular}{|c|c|c|}
\hline Efficiency & Effectiveness & Satisfaction \\
\hline Readability & Completeness & Awareness: taking notice \\
\hline Consistency & $\begin{array}{l}\text { Collaborative: perception } \\
\text { of mutual gain, emotional } \\
\text { incentive }\end{array}$ & Understanding: knowing \\
\hline Organization & $\begin{array}{l}\text { Communication effect on } \\
\text { consensus }\end{array}$ & $\begin{array}{l}\text { Consensus: willful } \\
\text { participation, engagement } \\
\text { and commitment }\end{array}$ \\
\hline Information visualization & $\begin{array}{l}\text { Pleasantly memorable: } \\
\text { attention, memory and } \\
\text { emotions }\end{array}$ & $\begin{array}{l}\text { Compliance: } \\
\text { associative action }\end{array}$ \\
\hline Learnability & $\begin{array}{l}\text { Sustainable: relational } \\
\text { resilience }\end{array}$ & $\begin{array}{l}\text { Positive exchange expe- } \\
\text { rience }\end{array}$ \\
\hline Flexibility & & $\begin{array}{l}\text { Sustainability of } \\
\text { agreements }\end{array}$ \\
\hline $\begin{array}{l}\text { Control of the interactive } \\
\text { and the static layers }\end{array}$ & & \\
\hline
\end{tabular}

Source: UX taxonomy applicable to transaction design adapted from the 'Combined taxonomy of usability components applicable to transactions' in Solarte-Vasquez et al., 2016.

The taxonomy combines drafting quality rules, and UX and UXI standards into a set applicable to transaction design. Three traditional quality attributes are placed at the primary level of UX in every smart system assessment: efficiency, effectiveness and satisfaction. Efficiency is determined by the relationship between inputs (costs and effort) and outputs; effectiveness measures the results or accomplishments facilitated by the efficiency factors, according to the goals of exchange and UX standards; and satisfaction, a novel consideration in contracting, resulting from the quality of the process and reflected in user engagement, and the validation (agreeability and acceptability) of the interface and the underlying interaction. SC adds a focus on collaboration, less stressing, friendlier transactional experiences, and the inclusion of some alternative texts such as screened visual elements. It should be highlighted that the legal requirements for the formation of binding agreements do not need to be enhanced by design, but could be communicated more clearly.

Readability, the first efficiency factor among the HCI usability standards, is the most important in contract drafting for being a basic condition for communication and understanding. Readability relies on language conventions that permit users the accurate identification of information in texts or images; hence, agreements cannot be said to have freely formed when agents are misinformed or not informed. 
The contractual usability of legal documents is reduced by default; they are hard to read due to the specialized language and unique categories of the law. Very few supporting visual conventions have been codified, which is problematic for the establishment of visual representations of legal knowledge as accuracy cannot be ensured. ${ }^{3}$ Nevertheless, lean contracting or the use of simplified texts, plain language and information visualization are other acceptable techniques. Next to language come formatting rules such as indentations, headings, labelling, etc.; layout tactics to highlight information; and size and appearance arrangements to help sharpen meanings. Consistency and organization are UX standards from HCI that may support the unity and coherence of legal texts (design, language, navigation, etc.), and decrease cognitive tensions by providing a logical flow of ideas. These factors amount to Visibility, that recommends the placement of content and commands at immediate reach, without noise. In interactive interfaces, the user should be able to detect functionalities at all times, when a design is Understandable, navigation becomes intuitive even to novice users. Information visualization in contract drafting holds a readability interest but deserves to be placed apart because of its potential to deliver alternative interfaces. ${ }^{4}$ The current knowledge on legal visualization is only forming and focuses mainly on experimental design studies (Passera, 2012). Learnability measures the speed at which a design becomes familiar to the user allowing fast completion of tasks (Ziefle, 2002). Flexibility and user control over interfaces are close to adaptivity and refer to personalization choices at the convenience of users. In SC the functionalities and affordances of the system should not be fixed, irreversible or imposed because the freedom of human agents is needed to prevent the system from regulating on their behalf. The UXI would not be upgraded if agents are disabled from modifying the agreements, correcting mistakes or changing their mind (undoing functions).

Contractual documents gain in effectiveness when the design process is successful, firstly because the text is comprehensive. The underlying relationships and the essential components of the contract should be identifiable in the interface, so completeness refers to the integrity and relevance of the content that is made accessible to users. Secondly, when Communication is improved through design, and meaning is accurately conveyed using appropriate data enrichment techniques. Lastly, if the upgrades become pleasantly memorable, improving attention, memory and producing positive emotions, so that strategy, transactional tool, and interaction can be expected to be sustainable.

3 The Creative Commons logos and traffic signs are some of the very few (http://creativecommons.org/).

4 Precision and recall are characteristics of data representation about correctness and completeness of graphics in information visualization (Tufte \& Graves-Morris, 1983). 
Satisfaction is a quality attribute about the exchange experiences and interactions of agents. The factors that define satisfaction result from effectiveness, producing genuine participation, understanding, empowerment and supporting contractual responsibility. The perception of the parties in traditional contracting is not as important and compliance is secured with remedies and sanctions. SC, in contrast, assumes that most of the times, promises are kept if contractual processes are responsive, flexible and trustable, and when all parties can benefit from collaborative interactions. Positive disposition and emotions could also be induced by pleasant aesthetics. Minimalistic designs have been found to help improve interfaces, discourage distractions and even be promotive of engagement (Tufte \& Graves-Morris, 1983).

Smart contractual management strategies have no apparent drawbacks but the many expected advantages need to be verified empirically, across organizations, sectors, industries and cultures. Non-legal values shaping the evolution of cultures, communities, organizations and individuals must be factored into the analysis of legally relevant interactions. The overall satisfaction with enhanced exchange experiences can be measured using the parameters recommended in HCI studies and considered accomplished when the interfaces have been duly transformed into relational tools that raise people's awareness, help understanding, inform consent and induce compliance.

Transactional design practices would smooth the transition to smart contracts and other systems of automated agency that can be no longer ignored by the social and legal sciences. In the meantime, human-centered design could help the institutionalization of collaboration in exchange. Businesses that formulate strategies with collaborative components contribute to the organization's sustainability. Based on usability slogans, other innovative possibilities can be anticipated, like the creation of multifunctional contracts of escalating levels of difficulty, different versions in layers with adaptable interfaces, controlled by the users. Alternatively, the generation of functionalities, affordances, and visuals to explain and clarify transactions may become automatic, generated when the system perceives the need to do so.

\subsubsection{Smart contracts}

SC fundamentally differs from smart contracts in respect to its characterization and operationalization, but proactive contractual management practices and automated transactions are compatible tools, with specific functions and applications in the digital markets. Smart contracts are not defined by the law but the literature generally as software agents/code, agnostic to legal values or 
ideologies, which fulfil obligations by command, and are enabled to execute rights in full control of certain assets (Szabo, 1997; Christidis \& Devetsikiotis, 2016; Koulu, 2016). The so-called smart contracts are often nested in distributed data structures, within shared ledgers, ${ }^{5}$ and do not necessarily derive from or refer wholly to a legal agreement. The code is inexpressive, incomplete and not amenable to the relational theory of exchange if standing alone. In contrast, the relational approach of SC may help transform the exchange environment from what it is: restrictive, antagonistic, contentious, competitive, divisive and costly, into participative, responsible, responsive and collaborative, and is developed in conformity with the existing legal frameworks and values.

Smart contracts are not the result of smart contracting processes. While SC revives the interest on contractual freedoms and contributes to sociotechnical systems, smart contracts could deprive the parties from having control of automated transactions. For example, smart contract commands are irreversible (Rouvroy \& Stiegler, 2016). Technically speaking, automation is unproblematic: blockchains can be embedded with data and commands which are activated upon pre-established conditions (inputs) to produce unambiguous results (outputs). Automation adds digital efficiency to the problem of enforcement and secures record-keeping, but efficiency is not the only or the most important concern of legal procedure theories; in fact, it can be argued that any contemporary legal system would be irritated by the notion of unrestricted efficiency overriding other and more complex values that need to be upheld such as the fundamental rights to freedom and property. The procedural justice pursued by due processes, according to the Rule of Law doctrine is substantially more important, due to a notion of fairness alien to computational methods that balances powers, provides assurances of respect for equality, transparency, and a reasonable chance for agents to participate in operations that could modify their legal rights and obligations (Kerikmäe et al., 2016). Furthermore, the due process stands against swift and summary proceedings. Smart contracts may be optimal execution management code, decentralized and fully autonomous, able to increase transactional accuracy, but not inherently fair.

Smart contracts are claimed to create incentives to make new trade relationships possible in non-human interaction inside the growing ecosystem of 'smart' devices such as in machine-to-machine commerce (Christidis \& Devetsikiotis, 2016). Examples would be self-recharging devices/appliances and cars which perform their own periodical revisions. However, it would be a limp argument to

5 Some of the most popular distributed ledger platforms are: AxCore (https://axoni. com/), Digital Asset Platform (http://digitalasset.com/), and Ethereum (https:// ethereum.org/). 
state that because distributed systems are self-executing and tamper-proof, trust is not necessary. Much to the contrary, the viability of these systems requires an enormous amount of trust in the enveloping agreements and it is hard to ensure the faithful correspondence between automated transactions and the agreement they aim to secure. Technology cannot understand in the sense of a state of mind or intuition; code does not detect whether agreements were fixed onto blockchain mistakenly, fraudulently or by force. The unrestricted dissemination of smart contracts could unleash regrettable chains of events, presuming everyone is well informed and self-reliant. Smart contracts are ill-suited for relational exchange and collaborative contractual management strategies. They resemble discrete transactions and do not admit proactive elements unless their usability is improved with user-friendly templates allowing human involvement. Some template ideas with simplified interfaces have begun to emerge, aiding some contractual stages rather than handling the whole lifecycle of contractual processes (Clack et al., 2016).

Adding a complex algorithmic layer to complicated legal texts and documents does not increase understanding, much less when using misleading characterizations. Moreover, the metaphoric use of contractual terminology to refer to smart contracts may be thought to justify enforcement, possibly rendering some transactions illegal. Smart contracts proponents must invest on the UX and UXI of these computational tools, and clarify that smart contracts do not equal complete legal agreements. Non-usable automated systems are likely to deepen asymmetries and structural conflicts. Consequently, a transition from welfarism and protectionism to a fully self-regulated scheme cannot be imposed or justified by any legal system in the absence of guarantees for groups with disadvantages, lack of competences and unhabituated or incapable of self-agency. The institutionalization of SC practices may provide the missing assurances in contracting processes where automation would only occur if consent has been verified or when human participation has been enabled, and safeguarded from unfair and abusive practices. This is why this paper argues that smarter contracting practices are key in transitioning from digitalization to these self-executing blockchain technologies.

Table 2 summarizes the areas where work on further specification is warranted to differentiate both concepts and research areas. 


\section{Table 2. Conceptual differences between smart contracting and smart contracts}

\begin{tabular}{|c|c|c|}
\hline Criteria & \begin{tabular}{|l} 
Smart contracts 'smart contract code' \\
-'contractware'- \\
\end{tabular} & Smart contracting \\
\hline Definition & $\begin{array}{l}\text { Distributed system for automated execu- } \\
\text { tion of events according to contractual } \\
\text { terms, typically contained on a shared } \\
\text { ledger. Comparable with digital manage- } \\
\text { ment rights }\end{array}$ & $\begin{array}{l}\text { Principled legal products and services design } \\
\text { activities focused on usability and UX of inter- } \\
\text { faces with legal relevance }\end{array}$ \\
\hline Scope & $\begin{array}{l}\text { Supports some stages of the lifecycle of } \\
\text { a contract }\end{array}$ & Covers all stages of the lifecycle of a contract \\
\hline $\begin{array}{l}\text { Governance } \\
\text { approach }\end{array}$ & $\begin{array}{l}\text { Promotes a discrete transaction view of } \\
\text { contracts }\end{array}$ & Operationalizes the relational view of exchange \\
\hline Technology & $\begin{array}{l}\text { Computational. Blockchain technologies } \\
\text { mainly }\end{array}$ & $\begin{array}{l}\text { Specialized contractual management strategy } \\
\text { supported by digital technologies }\end{array}$ \\
\hline Purpose & $\begin{array}{l}\text { Efficient execution, self-organizing, self- } \\
\text { help, compliance, independence from } \\
\text { state control }\end{array}$ & $\begin{array}{l}\text { Efficiency, effectiveness, satisfaction, sustain- } \\
\text { ability (relational), dispute prevention }\end{array}$ \\
\hline $\begin{array}{l}\text { Main } \\
\text { characteristic }\end{array}$ & Smart: automated by electronic means & $\begin{array}{l}\text { Smart: strategically sound, astute, scalable } \\
\text { onto electronic formats, transferable, sustain- } \\
\text { able, friendly, collaborative, relational, proac- } \\
\text { tive, socio technical (supported by technology) }\end{array}$ \\
\hline $\begin{array}{l}\text { Results/out- } \\
\text { come }\end{array}$ & $\begin{array}{l}\text { Preconceived outputs, enforcement, } \\
\text { accuracy. Examples: asset transfers, } \\
\text { conditional charges, etc. }\end{array}$ & $\begin{array}{l}\text { Multi-dimensional, not necessarily a deal or the } \\
\text { completion of a contractual provision, dynamic } \\
\text { performance and execution (may be trans- } \\
\text { formed according to unforeseeable events, } \\
\text { renegotiation, etc.) }\end{array}$ \\
\hline Features & $\begin{array}{l}\text { Perfect implementation leaving no room } \\
\text { for errors; unstoppable; tamper-proof; all } \\
\text { conditions must be decided beforehand; } \\
\text { operational semantics, freedom 'in' but } \\
\text { not 'out' } \\
\text { Other attributes: Security, anonymity (to } \\
\text { some extent); data integrity (record- } \\
\text { keeping); decentralized and independ- } \\
\text { ent; innovative }\end{array}$ & $\begin{array}{l}\text { Innovative dynamic conflict management; } \\
\text { traditional enforcement; susceptible to human } \\
\text { error; does not consider a contract can deter- } \\
\text { mine beforehand everything needed to know } \\
\text { about a legally relevant relationship; the literal } \\
\text { interpretation method is one of many ways to } \\
\text { process text; treats interfaces as boundary } \\
\text { objects; requires expertise on legal pragmat- } \\
\text { ics); freedom 'in' and 'out' }\end{array}$ \\
\hline $\begin{array}{l}\text { Informa- } \\
\text { tion and } \\
\text { knowledge } \\
\text { management } \\
\text { aspects } \\
\end{array}$ & $\begin{array}{l}\text { Indifferent to legal requirements for the } \\
\text { formation of valid agreements. Inex- } \\
\text { pressive, not user-friendly. Templates } \\
\text { proposals aided with basic graphical user } \\
\text { interfaces may help solve this problem } \\
\end{array}$ & $\begin{array}{l}\text { Usability criteria is a key component. Focused } \\
\text { on creating compliance incentives by increas- } \\
\text { ing understanding and reducing misinterpreta- } \\
\text { tion and information asymmetries }\end{array}$ \\
\hline Drawbacks & $\begin{array}{l}\text { Transaction costs economics approach, } \\
\text { motivates adversarial thinking, wasteful, } \\
\text { no scalability, pricey, tamper-locked, } \\
\text { distributed but not collaborative }\end{array}$ & $\begin{array}{l}\text { Not binding, requires institutionalization efforts } \\
\text { which increases investment costs (change), } \\
\text { contracting and lawyering styles are slow } \\
\text { changing institutions }\end{array}$ \\
\hline $\begin{array}{l}\text { Current } \\
\text { challenges }\end{array}$ & $\begin{array}{l}\text { Usability and synergies between the so- } \\
\text { cial and the technical components of this } \\
\text { technology; uncertainty on whether the } \\
\text { parameters for execution faithfully repre- } \\
\text { sent what was agreed by the parties. }\end{array}$ & $\begin{array}{l}\text { Dissemination, systematization and } \\
\text { unification of theoretical developments and the } \\
\text { practice. Slow consolidation of the research } \\
\text { field, and the automation rush. }\end{array}$ \\
\hline
\end{tabular}

6 A high-tech industry consortium (http://entethalliance.org/) launched in February 2017 a joint research project to explore the applications of Ethereum to a wide spectrum of transactions. 
Source: Adapted from the notes on Smart Contracting presented in the Computation methods in Law Workshop at Ulm University in November 2016 (http://www.uni-ulm.de/mawi/cml/).

Blockchain technologies and systems using AI are soaring in popularity in a haste that reminds of the problems of the social interconnected technologies: the content of the Web is full of mistaken and misleading data and imperfect code, produced and used by biased people who do not legitimately represent others, but influence decision-making on behalf of everyone. AI is bound to reinforce the inherent biases present at programming, leading to unintentional neglect of fundamental rights and ongoing sociotechnical processes such as increased inclusiveness, social responsibility or sustainability (Barocas \& Selbst, 2016). Crawford and Calo (2016) described the situation as follows: "AI research has a blind spot that needs to be addressed by a social system approach to automated decision making, where the AI system undergoes a test of how the system is interwoven with social processes, ethical principles and legal regulations."

Rejection of AI solutions and blockchain technologies in law would not be reasonable, but building a governance system where the problems generated by these tools are properly addressed is a must. Conventional theories and methods are poorly equipped for dealing with automated exchange and a network of autonomous devices is growing without having yet framed their applications in consideration to the affected social systems. Loosely attributing collaborative tags to machines and suggesting these could, on people's behalf, perform personal human activities such as understanding, agreeing, accepting and contracting is misleading. This is in part why automation is a reason for privacy, security, and trust on the Web to continue to be critical research issues (Wagner, 2016), not to mention the challenges that arise in view of the built-in indifference to individuals and minorities that algorithmic properties and big data unintentionally display (Barocas \& Selbst, 2016).

In little more than a decade the legal tech movement has raised awareness about alternative mind-sets and the need for changes and innovation in law and the legal profession (Susskind \& Susskind, 2015) but the prevalent updates are superficial. Lawyers are being helped to do what they have always done with 'legalware' such as storing and sharing contracts, and data analysis (see more on this and other applications of digital technologies in law in Kerikmäe \& Rull, 2016). Machine learning and the implementation of computational methods in law has barely been addressed or problematized in spite of the many areas where fundamental values could be affected (Roach, 2016). Nevertheless, the implementation of computational methods in the legal sphere is on the increase, 
and before or along with the automation of the law, UX and UXI developments will become necessary. Usability should not be mistaken for a trivial and secondary trend. Transaction quality factors are substantial to the existence of law by code and may determine the validity of a deed. The future does not end in automation, other types of texts and formats, voice and sound conventions may soon be found to constitute binding legal conduct. Contracts, transactions, pacts, and other legal acts could eventually be embedded on melodies, drawings, or even movements if unambiguously modifying relationships, or if those expressions are given the power of transforming rights and obligations. For the time being, imperfect human judgment and control seems much better than none over the growingly smarter contracts of the Internet of Everything (Hussain, 2017).

\section{Concluding remarks}

This paper unpacks the SC concept from characterization to specification, consolidating dispersed theoretical developments in the field of proactive law, business law for the digital markets and sociotechnical systems. The concept includes a proactive, relational and sustainable approach, proposed for strategic contractual management processes and the private governance of trade. The proposal challenges the traditional governance capacities of private exchange models to adapt to digital markets, and makes contributions to the theory and practice of relational exchange and trade that are manifold and cross-disciplinary. $\mathrm{SC}$ stems from the most advanced developments of the conflict management and dispute prevention field. It operationalizes Ian Macneil's original relational theory weaving contracting with threads of other sociotechnical exchange realities at different levels such as digital transformations and automation. $\mathrm{SC}$ relies upon few essential rules from the legal system and other formal institutions, and develops heuristics for contract drafting and transaction design through principles and UX/UXI factors.

The operationalization of $\mathrm{SC}$ as a relational theory is possible in environments where collaboration and contract responsibility or self-agency as the minimum conditions of viability and an institutional legitimizing framework are available. Awareness of these values would help the adoption and inspire the diffusion of the practices.

The institutional regulatory system and exchange environment of the EU, where the proactive movement has been officially promoted, legitimizes the 
SC approach. If the perspective spreads across the DSM, it is likely to increase consumer empowerment and with it, strengthen confidence in the European digital trade and business environment. The operationalization aspects of SC suggest to build into legally relevant exchange consumer protection by design, following the principled functional components of the proposal. The SC concept needs to be contrasted with smart contracts for a clear and detailed specification. The former is about improving the quality of regulations and applies to any legal document, deal, contract or transaction, automated or not, while the latter is a digital entity using a metaphor of widespread acceptance to refer to code or computational tools and self-executing transactions, preceded or not by valid agreements. SC could improve the usability of smart contracts and both may be integrated in digital contractual management but remain categorically differentiated from the foundational level.

María Claudia Solarte-Vásquez is a transaction design researcher and preventive law lecturer and consultant, interested primarily in regulatory quality and legitimacy. She is a PhD candidate at Tallinn University of Technology, obtained her LLM degree from the Washington College of Law of the American University, and completed her BA in Law and Political Sciences from the Law Department of Universidad Pontificia Bolivariana in Medellin, Colombia. From 1996, she has designed and lectured interdisciplinary courses from the preventive law perspective, and has been actively committed to ADR culture awareness, building and dissemination primarily in the Baltic region. She has also lectured Introduction to Law and Legal Environment of Business, Comparative Legal Systems and Governance, Legislative Policy, and Contracts, focusing on alternative contracting at the intersection of law, technology, business and design.

Katrin Nyman-Metcalf is visiting professor specialised in Law and Technology at Tallinn University of Technology, Estonia, and Programme Director of Research and Legal Aspects of the Estonian e-Governance Academy. For the past 20 years, she is active globally as consultant primarily in the area of communications law in the wide sense, including ICT regulation, privacy and data protection, media law, e-governance and cyber issues. She has worked in more than 50 countries, including post-conflict and developing states, with legal analysis and drafting, professional training and creation of regulatory authorities. Her $\mathrm{PhD}$ (Uppsala University, 1999) is on the law of outer space and she is Chairman of the International Relations Committee of the European Space Agency. 


\section{References}

Ahmadjian, C. L. (2016), 'Comparative institutional analysis and institutional complexity,' Journal of Management Studies, vol. 53, no. 1, pp. 12-27. https://doi.org/10.1111/joms. 12178

Argyres, N. \& Mayer, J. (2007), 'Contract design as a firm capability: An integration of learning and transaction cost perspectives,'Academy of Management Review, vol. 32, no. 4, pp. 1060-1077. https://doi.org/10.5465/AMR.2007.26585739

Ayres, I. \& Braithwaite, J. (1992), Responsive Regulation: Transcending the Deregulation Debate, Oxford: Oxford University Press.

Bagley, C. E. (2005), Winning legally: How legally astute management teams can use the law to create and capture value, Division of Research, Harvard Business School.

Baldwin, R. \& Black, J. (2008), 'Really responsive regulation,' The Modern Law Review, vol. 71, no. 1, pp. 59-94. https://doi.org/10.1111/j.1468-2230.2008.00681.x

Barnett, R. E. (1986), 'A consent theory of contract,' Columbia L. Rev., vol. 86, no. 2, pp. 269-321. https://doi.org/10.2307/1122705

- (1992), 'Conflicting visions: a critique of Ian Macneil's relational theory of contract,' Va. L. Rev., vol. 78, no. 5, pp. 1175-1206. https://doi.org/10.2307/1073395

Barocas, S. \& Selbst, A. D. (2016), 'Big data's disparate impact,' Cal. L. Rev., vol. 104, no. 3, p. 671. http://doi.org/10.15779/Z38BG31

Berger-Walliser, G.; Barton, T. D. \& Haapio, H. (2017), 'From visualization to legal design: A collaborative and creative process,' Am. Bus. Law J., vol. 54, no. 2, pp. 347-392. http://doi.org/10.1111/ablj.12101

Bilz, K. \& Nadler, J. (2013), 'Law, moral attitudes, and behavioral change,' in E. Zamir \& D. Teichman (eds.) Oxford Handbook of Behavioral Economics \& the Law, Oxford: Oxford University Press. http://doi.org/10.1093/ oxfordhb/9780199945474.013.0010

Braithwaite, J. (2011), 'The essence of responsive regulation,' University of British Columbia L. Rev., vol. 44, no. 3, pp. 475-520.

Bridoux, F. \& Stoelhorst, J. W. (2014), 'Microfoundations for stakeholder theory: Managing stakeholders with heterogeneous motives,' Strategic Management Journal, vol. 35, no. 1, pp. 107-125. https://doi.org/10.1002/smj.2089

Böhme, R. \& Köpsell, S. (2010). 'Trained to accept?: a field experiment on consent dialogs,' in Proceedings of the SIGCHI conference on human factors in computing systems, Atlanta: ACM, pp. 2403-2406. https://doi.org/10.1145/1753326.1753689

Cafaggi, F. (2007), 'Self-regulation in European Contract Law,' European Journal of Legal Studies, vol. 1, no. 1, pp. 163-218. 
Campbell, D. (2004), Ian Macneil and the relational theory of contract, Center for Legal Dynamics of Advanced Market Societies (CDAMS) Discussion Paper, Kobe University.

(2004), 'The incompleteness of our understanding of the law and economics of relational contract,' Wis. L. Rev., no. 2, pp. 645-678.

Christidis, K. \& Devetsikiotis, M. (2016), 'Blockchains and smart contracts for the internet of things,' IEEE Access, vol. 4, pp. 2292-2303.

https://doi.org/10.1109/ACCESS.2016.2566339

Clack, C. D.; Bakshi, V. A. \& Braine, L. (2016), 'Smart Contract Templates: essential requirements and design options,' arXiv e-print, arXiv:1612.04496.

Commonwealth of Australia (2000), Industry Self-Regulation in Consumer Markets, Report commissioned by the Australian Ministry of Finances and Regulation, August 2000. Retrieved from https://archive.treasury.gov.au/documents/1131/ HTML/docshell.asp?URL=02_chap1.asp [accessed Oct 2017]

Communication from the Commission to the European Parliament, the Council, the European Economic and Social Committee and the Committee of the Regions, EU Regulatory Fitness, COM/2012/746 final, Strasbourg, 12.12.2012. Retrieved from http://ec.europa.eu/smart-regulation/better_regulation/documents/com_2013 en.pdf [accessed Oct 2017]

Communication from the Commission. Action plan 'Simplifying and improving the regulatory environment', COM/2002/0278 final. Retrieved from http://eur-lex. europa.eu/legal-content/EN/TXT/?uri=celex:52002DC0278 [accessed Oct 2017]

Cortés, P., ed. (2016), The New Regulatory Framework for Consumer Dispute Resolution, Oxford: Oxford University Press.

https://doi.org/10.1093/acprof:oso/9780198766353.001.0001

Crawford, K. \& Calo, R. (2016), 'There is a blind spot in AI research,' Nature, vol. 538, pp. 311-313. https://doi.org/10.1038/538311

Cruz, C. O. \& Marques, R. C. (2013), 'Flexible contracts to cope with uncertainty in public-private partnerships,' International Journal of Project Management, vol. 31, no. 3, pp. 473-483. https://doi.org/10.1016/j.ijproman.2012.09.006

Dalhuisen, J. H. (2013), Dalhuisen on Transnational Comparative, Commercial, Financial and Trade Law Volume 2: Contract and Movable Property Law, London \& New York: Bloomsbury Publishing.

De Cremer, D.; Nguyen, B. \& Simkin, L. (2016), 'The integrity challenge of the Internet-of-Things (IoT): on understanding its dark side,' Journal of Marketing Management, vol. 32, nos. 1-2, pp. 1-14. http://doi.org/10.1080/026725 7X.2016.1247517

De Matos, E.; Amaral, L. A. \& Hessel, F. (2017), 'Context-aware systems: technologies and challenges in Internet of Everything environments,' in J. Batalla, G. Mastorakis, C. Mavromoustakis \& E. Pallis (eds.) Beyond the Internet of Things, 
Cham: Springer International Publishing, pp. 1-25. https://doi.org/10.1007/9783-319-50758-3_1

DiMaggio, P. \& Powell, W. (1983), 'The iron cage revisited: institutional isomorphism and collective rationality in organisational fields,'American Sociological Review, vol. 48, no. 2, pp. 147-160. https://doi.org/10.2307/2095101

DiMatteo, L. A. (2010), 'Strategic contracting: Contract law as a source of competitive advantage,' American Business Law Journal, vol. 47, no. 4, pp. 727-794. https://doi.org/10.1111/j.1744-1714.2010.01108.x

Directive 2000/31/EC of the European Parliament and of the Council of 8 June 2000 on certain legal aspects of information society services, in particular electronic commerce, in the Internal Market ('Directive on electronic commerce'), 17.07.2000. Retrieved from http://eur-lex.europa.eu/LexUriServ/LexUriServ. do?uri=CELEX:32000L0031:en:HTML [accessed Oct 2017]

Ebersold, K. \& Glass, R. (2016), 'The Internet of Things: a cause for ethnical concern,' Issues in Information Systems, vol. 17, no. 4, pp. 145-151.

EESC (2017), 'EU Digital Market: consumer protection must be top priority,' European Economic and Social Committee. Retrieved from http://www.eesc.europa. eu/?i=portal.en.press-releases.41899 [accessed Oct 2017]

European Commission (2001), 'Mandelkern Group on Better Regulation,' Final Report. Retrieved from http://ec.europa.eu/smart-regulation/better_regulation/documents/ mandelkern_report.pdf [accessed Oct 2017]

(2015a), Review of EU Consumer Law (Fitness Check), Consumers. Retrieved from http://ec.europa.eu/consumers/consumer_rights/review/index_en.htm [accessed Oct 2017]

(2015b), 'Shaping the Digital Single Market,' Digital Single Market Strategy, 25.03.2015. Retrieved from https://ec.europa.eu/digital-single-market/en/digitalsingle-market [accessed Oct 2015]

— (2016), 'Alternative and online dispute resolution (ADR/ODR),' Consumers. Retrieved from http://ec.europa.eu/consumers/solving_consumer_disputes/nonjudicial_redress/adr-odr/index_en.htm [accessed Oct 2017]

(2017), Results of the Fitness Check of consumer and marketing law and of the evaluation of the Consumer Rights Directive, Justice and Consumers, 29.05.2017. Retrieved from http://ec.europa.eu/newsroom/just/item-detail.cfm?item $\mathrm{id}=59332$ [accessed Oct 2017]

Fairfield, J. (2014), 'Smart contracts, Bitcoin bots, and consumer protection,' Wash. \& Lee L. Rev. Online, vol. 71, no. 2, pp. 35-299.

Feigenson, N. (2014), 'The visual in law: Some problems for legal theory,' Law, Culture and the Humanities, vol. 10, no. 1, pp. 13-23. https://doi. org/10.1177/1743872111421126 
Foss, N. J. \& Klein, P. G. (2016), 'Reflections on the 2016 Nobel Memorial Prize for contract theory,' Erasmus Journal for Philosophy and Economics, vol. 9, no. 2, pp. 167-180. https://doi.org/10.23941/ejpe.v9i2.234

Freeman, R. E. (1994), 'The politics of stakeholder theory: Some future directions,' Business Ethics Quarterly, vol. 4, no. 4, pp. 409-421. https://doi. org/10.2307/3857340

Goodin, R. E. (1998), The Theory of Institutional Design, Cambridge: Cambridge University Press.

Gunningham, N.; Grabosky, P. \& Sinclair, D. (1998), Smart Regulation: Designing Environmental Policy, Oxford: Clarendon Press.

Gunningham, N. \& Sinclair, D. (1999), 'Designing smart regulation,' in Economic Aspects of Environmental Compliance Assurance, OECD Global Forum on Sustainable Development.

Hesselink, M. W. (2015), 'Democratic contract law,' European Review of Contract Law, vol. 11, no. 2, pp. 81-126. https://doi.org/10.1515/ercl-2015-0006

Hollander-Blumoff, R. (2016), 'Fairness beyond the adversary system: procedural justice norms for legal negotiation,' Fordham L. Rev., vol. 85, no. 5, pp. 2081-2095.

Hussain, F. (2017), 'Internet of Everything,' in Internet of Things: Building Blocks and Business Models, Cham: Springer International Publishing, pp. 1-11. https://doi. org/10.1007/978-3-319-55405-1_1

IACCM (n.d.), International Association for Contract \& Commercial Management [Home page]. Retrieved from http://www.iaccm.com/ [accessed Oct 2017]

Ivens, B. S. (2002), 'Governance norms in relational exchange: What we do know and what we do not know,' in Proceedings of the 18th Annual IMP Conference, vol. 5, no. 7, Dijon: IMP.

Izmalkov, S. \& Sonin, K. (2017), 'Basics of contract theory,' Voprosy ekonomiki, no. 1.

Jaakkola, K. (2004), 'A way to successful and strategic contract management,' NordnetInternational Project Management Conference, Finland.

Jackson, D. (2016), 'Human-centered legal tech: integrating design in legal education,' The Law Teacher, vol. 50, no. 1, pp. 82-97. https://doi.org/10.1080/03069400.20 16.1146468

Kähler, L. (2013), 'Contract-management duties as a new regulatory device,' Law \& Contemp. Probs., vol. 76, pp. 89-103. https://doi.org/10.2139/ssrn.2285689

Kar, R. B. (2016), 'Contract as empowerment,' The University of Chicago Law Review, vol. 82, pp. 759-834.

Kerikmäe, T.; Hamulak, O. \& Chochia, A. (2016), 'A historical study of contemporary human rights: deviation or extinction?' Acta Baltica Historiae et Philosophiae Scientiarum, vol. 4, no. 2, pp. 98-115. https://doi.org/10.11590/abhps.2016.2.06

Kerikmäe, T. \& Rull, A., eds. (2016), The Future of Law and eTechnologies, Cham: Springer. https://doi.org/10.1007/978-3-319-26896-5 
Kerikmäe, T. \& Särav, S. (2015), 'Legal impediments in the EU to new technologies on the example of e-residency, Baltic Journal of Law \& Politics, vol. 8, no. 2, pp. 71-90.

Keskitalo, P. (2006), Contracts + Risks +Management=Contractual Risk Management? $\mathrm{PhD}$ dissertation, University of Tromsø, Norway.

Koulu, R. (2016), 'Blockchains and online dispute resolution: smart contracts as an alternative to enforcement,' Scripted: A Journal of Law, Technology \& Society, vol. 13, no. 1. http://doi.org/ 10.2966/scrip.130116.40

Lumineau, F. \& Malhotra, D. (2011), 'Shadow of the contract: How contract structure shapes interfirm dispute resolution,' Strategic Management Journal, vol. 32, no. 5 , pp. 532-555. https://doi.org/10.1002/smj.890

Macaulay, S. (1963), 'Non-contractual relations in business: A preliminary study,' American Sociological Review, vol. 28, no. 1, pp. 55-67.

https://doi.org/10.2307/2090458

Macher, J. T. \& Richman, B. D. (2008), 'Transaction cost economics: An assessment of empirical research in the social sciences,' Business and Politics, vol. 10, no. 1, pp. 1-63. https://doi.org/10.2202/1469-3569.1210

Mack, E. (1981), 'In defense of 'Unbridled' freedom of contract,' American Journal of Economics and Sociology, vol. 40, no. 1, pp. 1-15. https://doi.org/10.1111/j.1536-7150.1981.tb01366.x

Macneil, I. R. (1980), The New Social Contract: An Inquiry into Modern Contractual Relations, New Haven, CN: Yale University Press.

— (1983), 'Values in contract: internal and external,' Nw. UL Rev., vol. 78, no. 2, pp. $340-418$.

_ (1999), 'Relational contract theory: challenges and queries,' Nw. UL Rev., vol. 94, no. 3, pp. 877-907.

Malerba, F. (2002), 'Sectoral systems of innovation and production,' Research Policy, vol. 31, no. 2, pp. 247-264. https://doi.org/10.1016/S0048-7333(01)00139-1

Marshall, K.; Picou, S. \& Schlichtmann, J. R. (2004), 'Technological disasters, litigation stress, and the use of alternative dispute resolution mechanisms,' Law \& Policy, vol. 26, no. 2, pp. 289-307. https://doi.org/10.1111/j.02658240.2004.00013.x

McLaughlin, J.; McLaughlin, J. \& Elaydi, R. (2014), 'Ian Macneil and relational contract theory: evidence of impact. Journal of Management History,' vol. 20, no. 1, pp. 44-61. https://doi.org/10.1108/JMH-05-2012-0042

Menkel-Meadow, C. (2013), 'Crisis in legal education or the other things law students should be learning and doing,' McGeorge L. Rev., vol. 45, no. 1, pp. 133-160.

_ (2017), Dispute Processing and Conflict Resolution: Theory, Practice and Policy, Ashgate: Routledge. 
Norton Rose Fulbright (2016), 'Norton Rose Fulbright releases 2016 Litigation Trends Annual Survey', 15 September. Retrieved from http:/www.nortonrosefulbright. com/news/142350/norton-rose-fulbright-releases-2016-litigation-trends-annualsurvey [accessed Oct 2017]

Nylén, D. \& Holmström, J. (2015), 'Digital innovation strategy: A framework for diagnosing and improving digital product and service innovation,'Business Horizons, vol. 58, no. 1, pp. 57-67. https://doi.org/10.1016/j.bushor.2014.09.001

Nyman-Metcalf, K. \& Täks, E. (2013), 'Simplifying the law-can ICT help us?' International Journal of Law and Information Technology, vol. 21, no. 1, pp. 239268. https://doi.org/10.1093/ijlit/eat003

Opinion of the European Economic and Social Committee on 'The proactive law approach: a further step towards better regulation at EU level,' 2009/C 175/05, 28.7.2009. http://eur-lex.europa.eu/legal-content/EN/TXT/?uri=CELEX\%3A52008IE1905 [accessed Oct 2017]

Passera, S. (2012), 'Enhancing contract usability and user experience through visualization - an experimental evaluation,' in Information visualisation (iv): 2012 16th international conference on Information Visualisation, IEEE, pp. 376382. https://doi.org/10.1109/IV.2012.69

Passera, S. \& Haapio, H. (2013), 'Transforming contracts from legal rules to usercentered communication tools: a human-information interaction challenge,' Communication Design Quarterly Review, vol. 1, no. 3, pp. 38-45. https://doi.org/10.1145/2466489.2466498

Poppo, L. \& Zenger, T. (2002), 'Do formal contracts and relational governance function as substitutes or complements?' Strategic Management Journal, vol. 23, no. 8, pp. 707-725. https://doi.org/10.1002/smj.249

Posner, R. A. (2005), 'The law and economics of contract interpretation,' Tex. L. Rev., vol. 83, pp. 1581-2185.

Rindova, V. P. \& Kotha, S. (2001), 'Continuous "morphing": Competing through dynamic capabilities, form, and function,' Academy of Management Journal, vol. 44, no. 6, pp. 1263-1280. https://doi.org/10.2307/3069400

Roach, M. (2016), 'Toward a new language of legal drafting,' J. High Tech. L., vol. 17, pp. 43-177.

Romzek, B. S. \& Johnston, J. M. (2002), 'Effective contract implementation and management: A preliminary model,' Journal of Public Administration Research and Theory: J-PART, vol. 12, no. 3, pp. 423-453. https://doi.org/10.1093/ oxfordjournals.jpart.a003541

Rouvroy, A. \& Stiegler, B. (2016), 'The digital regime of truth: from the algorithmic governmentality to a new rule of law,' transl. by A. Nony \& B. Dillet, $L a$ Deleuziana: Online Journal of Philosophy, vol. 3, pp. 6-27. 
Ryan, R. M. \& Deci, E. L. (2006), 'Self-regulation and the problem of human autonomy: does psychology need choice, self-determination, and will?' Journal of Personality, vol. 74, no. 6, pp. 1557-1586.

https://doi.org/10.1111/j.1467-6494.2006.00420.x

Schulte-Nölke, H. (2015), 'The brave new world of EU consumer law-without consumers, or even without law?' Journal of European Consumer and Market Law, vol. 4, no. 4, pp. 135-139. https://doi.org/10.2139/ssrn.2657071

Schwartz, A. \& Scott, R. E. (2010), 'Contract interpretation redux,' The Yale Law Journal, vol. 109, no. 5, pp. 926-964.

Solarte-Vasquez, M. C.; Järv, N. \& Nyman-Metcalf, K. (2016), 'Usability factors in transactional design and smart contracting,' in The Future of Law and eTechnologies, Cham: Springer International Publishing, pp. 149-176. https://doi. org/10.1007/978-3-319-26896-5_8

Solarte-Vasquez, M. C. \& Rungi, M. (2017, forthcoming), 'Perceptions on collaboration affecting the viability of the Smart Contracting approach,' Journal of Management and Change.

Stephenson, P. (2013), 'Twenty years of multi-level governance: "Where does it come from? What is it? Where is it going?", Journal of European Public Policy, vol. 20, no. 6, pp. 817-837. https://doi.org/10.1080/13501763.2013.781818

Stinchcombe, A. L. (1985), 'Contracts as hierarchical documents,' in A. Stinchcombe \& C. Heimer (eds.) Organization Theory and Project Management, Oslo: N.U. Press.

Stoker, G. (1998), 'Governance as theory: five propositions,' International Social Science Journal, vol. 50, no. 155, pp. 17-28. https://doi.org/10.1111/14682451.00106

Susskind, R. \& Susskind, D. (2015), The Future of the Professions: How Technology will Transform the Work of Human Experts, Oxford: Oxford University Press.

Szabo, N. (1997), 'The idea of smart contracts,' Nick Szabo's Papers and Concise Tutorials, 6.

Teece, D. J. (2007), 'Explicating dynamic capabilities: the nature and microfoundations of (sustainable) enterprise performance,' Strategic Management Journal, vol. 28, no. 13, pp. 1319-1350. https://doi.org/10.1002/smj.640

Termeer, C. J.; Dewulf, A.; Breeman, G. \& Stiller, S. J. (2015), 'Governance capabilities for dealing wisely with wicked problems,' Administration \& Society, vol. 47, no. 6, pp. 680-710. https://doi.org/10.1177/0095399712469195

Tufte, E. R. \& Graves-Morris, P. R. (1983), The Visual Display of Quantitative Information, vol. 2, no. 9, Cheshire, CT: Graphics Press.

Van Ham, P. (2013), European Integration and the Postmodern Condition: Governance, Democracy, Identity, Abingdon: Routledge. 
Van Marrewijk, M. (2003), 'Concepts and definitions of CSR and corporate sustainability: Between agency and communion,' Journal of Business Ethics, vol. 44, no. 2, pp. 95-105. https://doi.org/10.1023/A:1023331212247

Van Oosterhout, J. H.; Heugens, P. P. \& Kaptein, M. (2006), 'The internal morality of contracting: Advancing the contractualist endeavor in business ethics,' Academy of Management Review, vol. 31, no. 3, pp. 521-539. https://doi.org/10.5465/ AMR.2006.21318915

Voss, J. P.; Bauknecht, D. \& Kemp, R., eds. (2006), Reflexive Governance for Sustainable Development, Cheltenham: Edward Elgar Publishing. https://doi. org/10.4337/9781847200266

Voß, J. P., \& Bornemann, B. (2011), 'The politics of reflexive governance: challenges for designing adaptive management and transition management,' Ecology and Society, vol. 16, no. 2. https://doi.org/10.5751/ES-04051-160209

Wagner, B. (2016), Draft Report on the Human Rights Dimensions of Algorithms. Committee of Experts on Internet Intermediaries, Council of Europe, MSINET(2016)06.

Wilhelmsson, T. (2004), 'Varieties of welfarism in European contract law,' European Law Journal, vol. 10, no. 6, pp. 712-733. https://doi.org/10.1111/j.14680386.2004.00240.x

Williamson, O. E. (1979), 'Transaction-cost economics: the governance of contractual relations,' The Journal of Law and Economics, vol. 22, no. 2, pp. 233-261. https:// doi.org/10.1086/466942

(1981), 'The economics of organization: The transaction cost approach,' American Journal of Sociology, vol. 87, no. 3, pp. 548-577. https://doi.org/10.1086/227496

Zahra, S. A. \& George, G. (2002), 'The net-enabled business innovation cycle and the evolution of dynamic capabilities,' Information Systems Research, vol. 13, no. 2, pp. 147-150. https://doi.org/10.1287/isre.13.2.147.90

Ziefle, M. (2002), 'The influence of user expertise and phone complexity on performance, ease of use and learnability of different mobile phones,' Behaviour \& Information Technology, vol. 21, no. 5, pp. 303-311. https://doi. org/10.1080/0144929021000048538 